\title{
Lorenzo Casini
}

\section{(Re-)Configurations of Islam in the Development of the Arabic Novel}

\section{Case Studies from Egypt and Kuwait}

\begin{abstract}
The existence of Islam in the Arabic novel is bound within epistemological constraints inscribed in the very form of the genre, and therefore transcends the contents of specific works. As one of the most distinctive expressions of modernity in the Arab world, the novel constitutes a meaningful locus to study the way Islam has been re-configured in relationship to some of the major intellectual debates that have swept through the Arab territories during the $20^{\text {th }}$ and the beginning of the $21^{\text {st }}$ century. This chapter examines the synchronic, diachronic and translocal dimensions of this process of reconfiguration, with a particular focus on the relationship between Islam and nationalism in Egypt and Kuwait.
\end{abstract}

\section{Introduction}

In 1997, at the beginning of a brief stay in Cairo as an exchange student at the University of al-Azhar, I was asked by the university administration to specify the aspects of Arabic studies that fascinated me most. When I mentioned my interest in the Arabic novel, I was assigned an individual supervisor who introduced me to a book that had been published only a few years before by the League of Islamic Universities based at al-Azhar: al-Adab al-islami darura (The Islamic literature is a necessity) by Ahmad Muhammad 'Ali. ${ }^{1}$ In this work, the author argues that modern narrative genres in Arabic literature have been the vehicle of anti-Islamic values, and that only the rise of an authentic Islamic literature can effectively contrast their pernicious influence. It is meaningful, I believe, that 'Ali's essay was the first book that an influential institution such as al-Azhar provided to a foreign student eager to deepen his knowledge of the Arabic novel. The author's project of establishing an "authentic Islamic literature" can easily be discredited as illusory, based as it is on a normative ideal of authenticity. However, 'Ali's acknowledgement of the problems that the narra-

1 'Ali 1991. 
tive genres of the novel and the short story pose to ideas of Islam promoted by traditional institutions of religious learning deserves more thoughtful attention.

Since the early $20^{\text {th }}$ century, the novel has become the most reputed genre of Arabic narrative among wide sectors of the reading public. One of its distinctive aspects is the way it served to spread the national ideal, not only as an imagined community but also as an all-encompassing paradigm. The novel was accepted within the Arabic literary canon only when the individual destiny of the characters intersected with the making of the modern nation, ${ }^{2}$ or, in other words, when Bildung narratives came to coincide with national narratives. ${ }^{3}$ Writing the nation through the Arabic novel has also meant that Islam was inscribed within the time-space of the nation-state, often in opposition to understandings of religion that the writers deemed incompatible with the imagined community projected by their narratives. Popular religiosity was re-signified as part of the national ethos while doctrinal visions of Islam were usually represented as alien to the national community.

This chapter examines the process of reconfiguration of Islam in the Arabic novel by focusing on three different dimensions: synchronic, diachronic and translocal. At the synchronic level, this process is analysed in reference to the specific time-space or chronotope ${ }^{4}$ embodied in the form of the realistnationalist novel as it emerged in Egypt during the early $20^{\text {th }}$ century, where it became a reference for other literary traditions in the Arab world. The diachronic dimension takes into account the transformation of ideas of nationalism and modernity in Egypt and its impact on literary texts. Finally, through the notion of translocality, ${ }^{5}$ this study investigates the effects of the circulation and transfer of the same literary topoi across the Arab world, and on their resignification in the light of different social-historical circumstances. With this aim, the last section of the chapter focuses on the relationship between Islam, nationalism and the novel genre in contemporary Kuwait.

In order to provide a synthetic description of these interrelated issues, a limited number of primary sources are considered: Muhammad al-Muwaylihi's neo-maqama Hadith 'Isa Ibn Hisham (What 'Isa Ibn Hisham told us, 1907), a narrative article published by Muhammad Husayn Haykal in 1925, the novels 'Awdat al-ruh (The Return of the Spirit, 1933) and Zuqaq al-midaqq (Midaqq

2 Selim 2004.

3 Casini, Paniconi, and Sorbera 2012, 39-152. The note refers to the first part of the book on the apprenticeship novel in Egypt. This part was written by Maria Elena Paniconi.

4 Bakhtin 1981.

5 Freitag and von Oppen 2010. 
Alley, 1947), written by the Egyptian authors Tawfiq al-Hakim and Najib Mahfuz respectively, and the novel Fi'ran Ummi Hissa (Mama Hessa's Mice, 2015) by the Kuwaiti writer Sa'ud al-San'usi.

\section{Ordering Islam within the bounds of modern narrative genres: From the neo-maqama to the 'formal realist' novel}

One of the basic assumptions of the sociology of literature is that a narrative genre is not a mere container in which meaning is solely produced by "diegetic events and speech acts", i.e. the content of each text. ${ }^{6}$ The form itself produces content because it conveys a particular way of structuring knowledge and a specific interconnection of time and space, or chronotope. The classical study The Rise of the Novel by Ian Watt relates the genesis of this genre in England to the spread of a philosophical current - epitomised by the work of René Descartes - which was "critical, anti-traditional and innovating". ${ }^{7}$ Descartes did much "to bring about the modern assumption whereby the pursuit of truth is conceived as a wholly individual matter" and the novel can be regarded as "the form of literature which most fully reflects this individualist and innovative reorientation". 8

In his pioneering study on the genesis of modern Arabic narrative discourse, Sabry Hafez elaborated a socio-critical approach modelled on Watt's analysis of the English novel. ${ }^{9}$ He was thus able to overcome the dominant genealogist interpretations of the rise of the Arabic narrative genres founded on the dichotomy between the Arabic classical heritage and the European literary tradition. He related the appearance of these genres to the deep social changes that had transformed the relationship among the individual, society and the inherited cultural tradition in several regions of the Arab world. According to Selim, this split between the subject and society was reflected in the new role assigned to the narrator as an individual observing society - the putative national reality - from an external and hegemonic viewpoint:

\footnotetext{
6 Bemon and Borghart 2010, 4.

7 Watt 1957, 12.

8 Ibid., 13.

9 Hafez 1993.
} 
In the same way that society came to be understood as a distinct and abstract field of human knowledge constructed around a subject/object relationship, so the act of narration itself came to reproduce the split implied in this new ontology. The narrator was no longer the custodian and transmitter of an accumulated civilization or turath (...). The new narrator was rather an individual standing 'outside' the collectivity, observing it, describing it, narrating it, not as a communal historian but from a position that embodied a subjective but nonetheless authoritative and hegemonic point of view (...). The act of narration thus came to embody a slippery relationship between the narrating subject and the ambiguous, abstract collectivity defined as 'society' which represents a putative national reality. ${ }^{10}$

Muhammad al-Muwaylihi's neo-maqama Hadith 'Isa Ibn Hisham (What 'Isa Ibn Hisham told us, 1907) can be regarded as the last great literary attempt to "contain"11 the representation of the modern world within the formal constrains of the classical genre of the maqama. ${ }^{12}$ The author's appropriation of the maqama form to represent modern Egyptian society stemmed from his particular understanding of Islamic Reformism which was inspired by the ideas of Muhammad 'Abduh. While the latter reinterpreted key categories of the Islamic tradition in the light of modern debates, al-Muwaylihi charged a traditional narrative form with new meaning. Both endeavours, however, led to unintended results:

To show that Islam can be reconciled with modern thought, and how it can be, was one of 'Abduh's major purposes. (...) In this line of thought maslaha gradually turns into utility, shura into parliamentary democracy, ijma' into public opinion; Islam itself becomes identical with civilization and activity, the norms of nineteenth century social thought. (...) Once the traditional interpretation of Islam was abandoned, and the way open to private judgement, it was difficult if not impossible to say what was in accordance with Islam and what was not. Without intending it, 'Abduh was perhaps opening the door to the flooding of Islamic doctrine and law by all the innovations of the modern world. He had intended to build a wall against secularism, he had in fact provided an easy bridge by which it could capture one position after another. ${ }^{13}$

What Albert Hourani noted about the possible implications of 'Abduh's approach to Islamic reformism, as providing an easy bridge to "all the innovations of the modern world", can be transferred to the narrative strategies of Hadith 'Isa Ibn Hisham. Once the maqama was charged with a modern conception of time and space, the way was paved for the genre's very dissolution.

\footnotetext{
10 Selim 2004, 13.

11 Jameson 1981.

12 Casini 2011, 29-45.

13 Hourani 1983, 144.
} 
The main difference between Hadith 'Isa Ibn Hisham and the traditional maqama is the particularising approach to the representation of time and space, as it is testified also by the subtitle $A$ Period of Time (Fatra min al-zaman) which was given to the work when it was first published in serialised form between 1898 and 1900, in the newspaper published by the father of the author. ${ }^{14}$ Whereas in the pre-modern maqama the setting and the historical time of the events do not constitute a relevant feature of the narrative, al-Muwaylihi's neomaqama is devoted to scrutinise the transformations undergone by Egyptian society - and the city of Cairo in particular - in the specific time-span of the second half of the $19^{\text {th }}$ century.

The choice of the historical figure of Ahmad Pasha al-Manikali (Muhammad 'Ali's Minister of War) as the hero of the maqama, serves as the text's key narrative device to compare and evaluate the initial and final moments of the period of time under scrutiny. The Pasha is made resurrect after fifty years from his death and immediately meets the narrator ('Isa Ibn Hisham), a fictional character presented as a writer of al-Muwaylihi's generation who conveys the voice of the author. During the first part of the text, the Pasha's bewilderment towards the new social-political order and its institutions generates irony and serves to emphasise the depth of the transformations occurred between his death and resurrection. In the early episodes of the narrative, the Pasha exhibits a traditionalist orientation and rejects every aspect of the modern society. Conversely, the narrator, while displaying a critical attitude towards the Egypt of the time, does not manifest any nostalgia for the past and invokes a reformist approach based on an innovative interpretation of the Islamic shari'a.

This reformist role assigned to literature, which permeates 'Isa's focalisation and the text as a whole, is made explicit in a passage in which the narrator identifies journalists as exemplary Muslims and defines their function by referring to the Koran. This parallel is all the more significant when one bears in mind that al-Muwaylihi himself was a journalist and that Hadith 'Isa Ibn Hisham was first serialised in a newspaper:

[Newspapers] are one of the aspects of Western civilizations that we have imported into our society. The purpose of issuing papers is to publish articles which give due credit for value and merit, and to rebuke depravity; to criticise bad actions and encourage good ones, to draw attention to points of imperfection and to urge people to correct mistakes

14 The text was published in the newspaper Misbah al-sharq funded by Ibrahim al-Muwaylihi. See Roger Allen's detailed introduction to his critical edition of the English translation of Hadith 'Isa Ibn Hisham (al-Muwaylihi 1992a). 
(...). To sum up, those who run the press occupy the position of "those who command good deeds and rebuke bad deeds" ${ }^{15}$ as referred to in the Islamic Shariah. ${ }^{16}$

The crisis of the maqama form and the recognition of the novel as a genre of high literature can only be properly understood in the context of wider historical and cultural developments, which contributed to a redefinition of the social and symbolic role of Islam. In Egypt, in particular, the weakening of PanIslamism as a viable political option - especially after the fall of the Ottoman Empire - boosted the rise of the ideological current of modernism which replaced Islamic reformism as the dominant discourse among the local élite. The intellectual whose articles mostly contributed to shaping the new modernistnationalist discourse is Muhammad Husayn Haykal, who is significantly also the author of Zaynab (1913), which a long critical tradition identified as the "first Arabic novel". ${ }^{17}$ In the period between the outbreak of the First World War and the mid-1920s, Haykal developed an intense journalistic activity. ${ }^{18}$ His newspaper articles rooted Egyptian nationalism in the Pharaonic past and popularised environmental determinism as a key notion to define "the Egyptian national personality". Haykal's Pharaonist articles caused a radical break with the Islamic tradition. However, like the writings of the European anti-Lumières, ${ }^{19}$ these articles recognised the importance of religion as a tool of governance and underscored its mediating role between the new national élite and the masses.

Haykal's vision of the social role of religion is articulated in unequivocal terms in an article on the Pharaonic cult of the Apis calf, written in a narrative style and published in 1925. The author's ideas are expressed by the character of a middle-aged man who counters the criticism of a younger person on the sub-

15 Sura 9 verse 112.

16 al-Muwaylihi, 1992b, 136-37.

17 Gibb was the first to propagate the view of Zaynab as the first Arabic novel in 1933. His views, however, echoed the opinion of other Egyptian critics and of Haykal himself who contributed to popularise this view (Hassan 2017, 43).

18 On this aspect see in particular the contributions by Charles Smith (1983), Israel Gershoni and James Jankowski (1986).

19 With this term, Zeev Sternhell refers to an intellectual tradition that spans from Herder and Burke in the second half of the $18^{\text {th }}$ century to the present day, and includes thinkers such as Taine, Renan, Carlyle, Le Bon and Spengler, all of whom had a direct influence on Haykal. In Sternhell's view, the anti-Enlightenment cannot be described as a counter-revolution but is hereditary of another revolution that opposed the universalism of the Enlightenment, and nourished conceptions of modernity that were in contrast to the generalisation of rights and the primacy of the individual (Sternhell 2009). On Haykal's anti-Enlightenment modernity see Casini (2019). 
ject of the religion of the Ancient Egyptians. This latter character observes that in modern eyes worshipping a calf seems a patent ingenuity if not a collective hallucination. The middle-aged man, however, provides a rational justification for worshipping the calf: Apis was a splendid intermediary with the masses of Ancient Egypt, who had attached their "good fantasies" to the calf. He adds that these fantasies (awham), albeit despised today, are the basis of "the latent eternal strength" (al-quwwah al-kaminah al-khalidah) ${ }^{20}$ that guides their activity towards beneficial achievements (al-salih al-mufid).

Having listened to these arguments, the young man remarks that there is no harm in believing in the values venerated in Ancient Egypt, such as peace, good and prosperity. He is unable to understand, however, why these values cannot be worshipped per se but have to be associated with idols such as Apis or Osiris. The middle-aged man explains this to him, drawing on an example from the modern world. Anyone who visits a power station and sees the machines that produce a gigantic amount of energy cannot but feel a sense of wonder. If, on the other hand, a power station is described to people whose lives depend on it, they will undoubtedly begin to worship those who realised it. He concludes that "the same happened to the mass (al-sawad) of our ancestors with what their cultural élite (dhawu al-ra'y minhum) told them about Isis, Osiris, Apis and the rest of the deities". ${ }^{21}$ In the final part of the article, the middle-aged man draws a parallel between Islam and the religion of Ancient Egypt. At the time of the Pharaohs, he asserts, priests and other men of religion believed in a single God. Deities such as Apis and Osiris were merely symbols that embodied heavenly meanings easily understood by the masses. In his view, the same happens in Islam, where men of religion profess there is only one God but the masses worship the symbols of their faith, not unlike the calf in antiquity. ${ }^{22}$

The general vision of Islam and religion that the article on Apis conveys, bears few resemblances with the Islam of al-Muwaylihi's neo-maqama and Islamic jurisprudence. Religion is no more conceived as an end in itself but as a

20 The middle-aged man's utterance here is reminiscent of the final words in the following passage from The Crowds by Gustave Le Bon: "As far as the majority of their acts are considered, crowds display a singularly inferior mentality; yet there are other acts in which they appear to be guided by those mysterious forces which the ancients denominated destiny, nature or providence, which we call the voices of the dead and whose power it is impossible to overlook although we ignore their essence. It would seem, at times, as if there were latent forces in the inner being of nations which serve to guide them [emphasis added]" (Le Bon 2001, 6).

21 Haykal 1968, 277.

22 Ibid., 280-87. 
tool of governance which is inscribed within an elitist project of modernisation. It is this vision of Islam that shapes the early phase of the Arabic nationalist novel, which in turn finds its most coherent expression in the 1933 work by Tawfiq al-Hakim 'Awdat al-ruh.

\section{Islam, modernity and the nation: From 'Awdat al- ruh by Tawfiq al-Hakim to Zuqaq al-midaqq by Najib Mahfuz}

The novels 'Awdat al-ruh (The Return of the Spirit) and Zuqaq al-midaqq (Midaqq Alley), published in 1933 and 1947 respectively, are two classics of modern Arabic narrative. Their divergent configurations of the relationship between Islam, modernity and the nation document how diachronic transformations in conceptions of modernity and Egyptian nationalism impacted the representation of Islam. 'Awdat al-ruh can be regarded as the most coherent and influential national allegory of Egypt. Set at the time of the national revolution of 1919, this work redefines the Egyptian community on the basis of the environmental determinism theorised by Hippolyte Taine in the $19^{\text {th }}$ century and reelaborated by Haykal as the key foundation of Egyptian territorial nationalism. The "spirit" (al-ruh) to which the title refers to, is the one of Pharaonic Egypt and its "return" coincides with the re-birth of the nation. The new imagined community is rooted in the myths and religion of Pharaonic Egypt - with explicit references to Isis, Osiris and The Book of the Dead - but also in a 'culturalised Islam' conceived as one of the main 'glues' of the nation, together with the environment of the Nile Valley and the cultural inheritance of Ancient Egypt.

Awdat al-ruh is the only case of a prototypical and accomplished Bildungsroman in the early stages of the development of the Egyptian novel. While in previous and later works the social conditions of Egypt are represented as impediments for the full development of the hero's personality and his accommodation within the existing social order, in this work the protagonist finds a meaningful existence within the Egyptian society thanks to his involvement in the nationalist movement. The hero (Muhsin) lives in Cairo in the house of his uncles, as part of an extended family which represents the national microcosm allegorically, and is significantly referred to as $a l-s h a^{\prime} b$ (the people). The pro- 
logue emphasises the extraordinary unity of $a l-s h a c b,{ }^{23}$ their rural origin and their present apathy and weakness. The story begins when the male members of the family become infatuated with a girl (Saniyya) with whom the protagonist identifies the Egyptian goddess Isis. The passion that Saniyya arises among the men of the family allows "the people" to overcome their apathy although it also produces feelings of envy, competition and division. The unity of the family is only restored after the heroine/Goddess marries a neighbour and leaves Cairo. When the national revolution of 1919 erupts, the male members of the family join the protests and redirect their passions towards the nationalist cause.

The figurative dimension of the narrative as a national allegory becomes explicit in the brief sequence of chapters that opens the second part of the novel and which is mostly set in the estate of Muhsin's parents, near the city of Damanhur. The first chapter of this part performs the ambitious task of redefining the social role of Islam in radically new terms. It takes place in the train that brings the protagonist from Cairo to Damanhur and consists of a conversation between the passengers of the compartment in which the protagonist is seated. The conversation begins when a Coptic effendi praises the spirit of solidarity among the Egyptian people and contrasts it with the prevalent individualism of the Europeans. When a religious shaykh seated next to him observes that Europe "is a country without Islam", a third passenger (who notes the embarrassment of the Coptic passenger) corrects him: "You mean, Mr. Shaykh, it is a land without hearts, not like our country where we are all brothers whether Copts or Muslims". ${ }^{24}$ At this point a fourth passenger, "an enlightened man" intervenes in the conversation and redefines Islam as a cultural component of the Egyptian nation. The rest of the passengers - Copts and Muslims, the shaykh and the effendis - agree on this definition:

\begin{abstract}
Another passenger, an enlightened man, noticed the same thing. He entered into the discussion and began adroitly to amend the statement until he showed those present that the word "Islam", which was current in Egyptian use at all levels of society, really had no religious or sectarian stamp. Its meaning and import were, rather, the emotion of mercy, a goodness of hearth, and a union of hearths. These were emotions to be found in Egypt and not in Europe. There, the poison of utility had spread to the souls of the Europeans. A dogeat-dog strife prevailed with emphasis on the personal welfare of the individual. Every-
\end{abstract}

23 The exceptional unity of the Egyptian nation is one of the tenets of Egyptian territorial nationalist as theorised by Muhammad Husayn Haykal. This unity, which supersedes that of other nations, is traced back to the extraordinary uniformity of the natural environment of the Nile Valley. On this respect see in particular the four articles on Qasim Amin initially published by Haykal in 1916 (Haykal 1968, 91-127).

24 al-Hakim 2019, 171. 
one, both the turbaned and the befezzed, pondered this statement and this gloss. He seemed to have disclosed to them a reality that had previously been concealed under the cloak of that word. They liked what he had said and appreciated it. The topic was closed. ${ }^{25}$

Published only fourteen years after al-Hakim's work, Zuqaq al-midaqq offers a very different image of the Egyptian nation. In contrast to the cohesive and organic representation of the community in 'Awdat al-ruh, Mahfuz's novel centres on the lacerating effects of modernisation in the context of the British control of the country. These lacerations are represented through the juxtapositions of two different chronotopic microcosms. On the one side stands medieval Cairo, of which Midaqq Alley functions as a synecdoche, and on the other the modern city. The alley is subjected to the ordering principle of Islamic tradition and a cyclical time epitomised by the character of a storyteller who keeps reelaborating on his limited centuries-old repertoire. Besides being used as a synecdoche of the national culture, the alley is also represented as a residual cultural universe engulfed in the evenemential temporality of the modern city. The latter exerts an uncontrollable attraction over the young residents of the alley, although the exit from the boundaries of medieval Cairo is traumatic for all.

In the characterisation of Midaqq Alley, Islam is identified with a fatalistic approach to life that binds the subject to the social world and prioritises adherence to traditional values over individual will. This understanding of Islam is expressed in several passages of the opening chapter: the narrator describes the misery brought by the War as the natural outcome of "our own wickedness"; the several haemorrhages caused by the surgeries of an improvised dentist (named "Dr. Bushi", despite not being a doctor) are interpreted as a sign of the divine will, while the leitmotiv of the pious character of Sayyid Ridwan al-Hussayni is that "He gave and He has taken back; all things are at His command and all things belong to Him. It would be blasphemous to sorrow". ${ }^{26}$ The lack of individual will which distinguishes life in the alley is symbolised by the sweet seller Kamil. The first character to appear in the novel, Kamil is described as an obese man who can barely move and whose life is no more than "a prolonged sleep".

The novel genre is not conceivable within the conception of life which permeates the chronotopic universe of the alley. Time is "viscous" and "sticky" and does not know any movement forward. In this sense it is an "ancillary" time which resembles the one of the provincial town that Bakhtin describes with reference to Flaubert's Madame Bovary:

25 al-Hakim 2019, 171-72.

26 Mahfuz 1992, 9. 
Here there are not events, only doings that constantly repeat themselves. Time here has no advancing historical movements; it moves rather in narrow circles (...). Time here is without event and therefore almost seems to stand still. There are no meetings and no partings. It is a viscous and sticky time that drags itself slowly through space. And therefore it cannot serve as the primary time of the novel. Novelists use it as an ancillary time, one that may be interwoven with other noncyclical temporal sequences (...). It often serves as a contrasting background for temporal sequences that are more charged with energy and event. ${ }^{27}$

If Zuqaq al-midaqq exists as a novel it is only because the evenemential time of modernity embodied by the new city intrudes into the space of the Alley. The story takes place in a particular moment in the history of Midaqq Alley, endowed with symbolic significance: Some workers are fixing a radio at the local café, a device which brings the events of the outside world to the Alley. The character who changes the destiny of the heroine - a pimp - also comes from the modern city. He is able to gain access to the closed universe of the Alley by joining the celebration of an electoral campaign which temporarily subverts the cyclical rituality of life.

The case studies of 'Awdat al-ruh and Zuqaq al-midaqq exemplify how the narrative existence of Islam in the Egyptian novel - in terms of functions, images and representations - is strictly interrelated with the texts' general narrative strategies. Specific images of Islam do not convey the religious beliefs or actual perceptions of the authors but are deployed strategically, often in relationship to the construction of alternative representations of the national space. AlHakim's vision of the harmonic integration of the subject within a rising national community shaped by a 'renovated' understanding of Islam ('Awdat al-ruh), was replaced, in the aftermath of the Second World War, by Mahfuz's pessimistic vision of the modernising process, and the association of Islam with a residual chronotopic universe (Zuqaq al-midaqq).

\section{From mid-20 ${ }^{\text {th }}$ century Egypt to contemporary Kuwait: Fi'ran Ummi Hissa by Sa'ūd al-San'ūsī}

The final section of this chapter moves from the Egyptian context of the early and mid- $20^{\text {th }}$ century to contemporary Kuwait. This jump in space and time allows us to tackle the question of the translocal dimension of the reconfigura-

27 Bakhtin 1981, 247. 
tions of Islam in the Arabic novel. In the descriptive sense, translocality "designates the outcome of concrete movements of people, goods, ideas and symbols which span spatial distances and cross boundaries" and, as a research perspective, "aims at highlighting the fact that the interactions and connections between places, institutions, actors and concepts have far more diverse, and often even contradictory effects than is commonly assumed". ${ }^{28}$ As the following section will show, the case of the contemporary Kuwaiti novel is particularly meaningful to exemplify the possible outcomes of the circulation of the novel genre across different Arab territories.

Kuwait has a young, but well-established, tradition of novelistic writing with authors such as Isma'il Fahd Isma'il (1940-2018) and Layla al-'Uthman (b. 1945) who gave a significant contribution to the development of the genre during the 1970s and 1980s, respectively..$^{29}$ However, it was the traumatic experience of occupation of the country during the Iraq-Kuwait war of 1990-1991, and the ensuing wave of Kuwaiti territorial nationalism, which led to a wide social recognition of the genre and to its identification as an important means to inscribe religion within a renovated national imaginary. This social significance attributed to the novel in the aftermath of the war, empowered the Kuwaiti authors of the generation of the 1990s, and placed them in a similar situation to that of the Egyptian pioneers of the genre during the first decades of the $20^{\text {th }}$ century. It is not by chance, therefore, that Kuwaiti authors such as Sa'ud al$\mathrm{San}^{\mathrm{u}} \mathrm{usi}^{30}$ found inspiration in classic Egyptian novels and in their literary topoi. In al-San'usi's novel Fi'ran Ummi Hissa (Mama Hessa's Mice, 2015), Islam enjoys a complex narrative existence as both a unifying trait of the national culture and (in its sectarian articulations) as a threat to the very existence of the nation. Through the allegory of the plague spread by mice, al-San'usi represents the uncontrollable proliferation of religious sectarianism in Kuwait from the late 1980s to the imminent dystopic future of 2020, and the way sectarian violence undermines the very existence of the nation.

In a private conversation that I had with the author in February 2018, he explained to me that Mahfuz's realist novels had influenced his style more than the works of other Arab writers of younger generations. These words are confirmed in Fi'ran Ummi Hissa by the way the text handles the representation of

28 Freitag and von Oppen 2010, 1-5.

29 Tijani 2017, 283-84.

30 Sa'ud al-San'usi, born in 1981, won the Arabic booker prize in 2013 with his second novel Saq al-bambu (The Bambu Stalk) centred on the themes of migration and citizenship rights. Fi'ran Ummi Hissa is his third novel. 
space and describes the old quarter of al-Surra in Kuwait City. The dialectic between the Alley and modern Cairo in Mahfuz's Zuqaq al-midaqq is paralleled in Fi'ran Ummi Hissa by the relationship between al-Surra and Kuwait City. Like the Alley in Mahfuz's novel, al-Surra lives a double narrative existence. On the one hand, it stands as a timeless microcosm of the nation, endowed however with a mythical dimension which is absent in Zuqaq al-midaqq. On the other hand, this neighbourhood is depicted as part of the wider urban space of Kuwait City and subjected to the flow of an evenemential temporality.

The elderly character of mama Hissa is the emblem of al-Surra as a mythical and unitarian synecdoche of the nation. In her house and courtyard, the protagonist spends the most significant moments of his childhood in company of his close friends: the Sunni Fahd - mama Hissa's grandchild - and the Shia Sadiq.

Although she is an illiterate woman, mama Hissa possesses a deep wisdom rooted in the cosmopolitan history of the country. Hissa's popular religiosity is part and parcel of the national culture and permeates the education she conveys to the children of the neighbourhood through proverbs and the ritual of storytelling. Another distinctive aspect of this microcosm is the presence of inhabitants of foreign origin, who are represented as an inner component of the social texture.

Next to this image stands that of al-Surra as a district of Kuwait City, a space undergoing important transformations that affect the whole capital during a time span of forty years that goes from the end of the Iran-Iraq War to the imaginary civil war that takes place in 2020. This historical-dystopian temporality is associated with the characters of the Sunni Salih and the Shia 'Abbas, fathers of Fahd and Sadiq, respectively. Through their contrasted relationship, they bring into al-Surra the 'fire' of religious sectarianism which undermines the unity of the three friends and, by extension, the unity of the nation.

The novel consists of four parts, each of them bearing the name of a mouse: sharar (spark), laza (flame), jamar (ember) and ramad (ashes). The sequence of these names conveys the allegorical sense of the story as the development of a fire that reduces the country to ashes. The spread of sectarian discourse, however, is actively contrasted by mamma Hissa and, once she passes away, by the protagonist. The most faithful heir of Hissa's cultural legacy, the hero becomes a writer of short stories for children and convinces Fahd, Sadiq and some other friends to establish Awlad Fu'ada. The purpose of this organisation, which stands as a microcosm of the nation, is to fight the plague of sectarian discourse through a radio, a website and a Twitter account. As a means of resisting the lacerating forces of religious sectarianism, the protagonist also writes an auto- 
biographical novel whose title, Irth al-nar (The inheritance of fire), refers to the long-lasting effects produced by sectarian discourse. This text is incorporated in Fi'ran Ummi Hissa as a novel within the novel, and its editorial trajectory intersects with that of the work by al-San'usi. While writing his book, the hero is pressured by his Lebanese publisher to cut some chapters in order to avoid censorship. This is a fictional anticipation of the actual fate of Fi'ran Ummi Hissa whose sale is still forbidden in Kuwait at the time of writing. The fate of alSan'usi's novel echoes the work's thematic concern with the collapse of the nation and testifies how the inscription of Islam within the national paradigm is being increasingly disputed.

\section{Conclusions}

As one of the most distinctive expressions of modernity in the Arab world, the novel constitutes a meaningful locus to study the way Islam has been reconfigured in relationship to some of the major intellectual changes that have swept over the Arab territories during the $20^{\text {th }}$ and the beginning of the $21^{\text {st }}$ century. The study of Islam as an intrinsic narrative element of the novel genre does not entail describing the novels under scrutiny as Islamic, or overemphasising the religious dimension of the texts. In the three novels that have been examined, Islam permeates the national paradigm in several ways: as a distinctive trait of the new imagined community, as a pervasive presence of a residual socialcultural entity, or as a threat to the very existence of the nation.

These interconnections with nationalism have been qualified as "synchronic" insofar as they can be traced back to a constitutive and structural dimension of the Arabic novel. The comparative analysis of 'Awdat al-ruh and Zuqaq almidaqq, however, has highlighted the importance of the diachronic development of territorial nationalism as well as the structural transformations that have occurred within the very form of the novel. Finally, the analysis of Fi'ran Ummi Hissa shows how different novelistic traditions are shaped by local dynamics and the specific historical experiences of different Arab territories. In the case of the young generation of Kuwaiti writers, the novel has become a bulwark of the nation against the divisive drive of religious sectarianism, but also a tool to renegotiate the national space. 


\section{Bibliography}

'Ali, Ahmad Muhammad. 1991. al-Adab al-islami darura. al-Qahira: Rabita al-jami'at al-islamiyya.

Bakhtin, Mikhail. 1981. The Dialogic Imagination: Four Essays. Austin: University of Texas Press.

Bemong Nele, Pieter Borghart, Michel De Dobbeleer, Kristoffel Demoen, Koen De Temmerman, and Bart Keunen, eds. 2010. Bakhtin's Theory of the Literary Chronotope. Gent: Academia Press.

Casini, Lorenzo. 2011. "Occidentalism as the Political Unconscious in the Literary Construction of the Other." In Orientalism and Conspiracy. Politics and Conspiracy Theories in the Islamic World, edited by Arndt Graf, Schirin Fathi, and Ludwig Paul, 29-45. London: I.B. Tauris.

Casini, Lorenzo. 2019. “Muḥammad Ḥusayn Haykal’s Anti-Enlightenment Modernity 19161925." Oriente Moderno 99: 30-47.

Casini, Lorenzo, Maria Elena Paniconi, and Lucia Sorbera. 2012. Modernità arabe. Nazione, narrazione e nuovi soggetti nel romanzo egiziano. Messina: Mesogea.

Freitag, Ulrike, and Achim von Oppen, eds. 2010. Translocality. The Study of Globalizing Processes from a Southern Perspective. Brill: Leiden.

Gershoni, Israel, and James Jankowski. 1986. Egypt, Islam, and the Arabs: The Search for Egyptian Nationhood 1900-1930. Oxford: Oxford University Press.

Hafez, Sabry. 1993. The Genesis of Arabic Narrative Discourse. London: Saqi.

al-Hakim, Tawfiq. 1984 [1933]. 'Awdat al-ruh. Bayrut: Dar al-kitab al-lubnani. (Translated by William Maynard Hutchins: al-Hakim, Tawfiq. 2019. Return of the Spirit. London: Penguin).

Hassan, Waïl S. 2017. Toward a Theory of the Arabic Novel, in The Oxford Handbook of Arab Novelistic Traditions, edited by Waïl S. Hassan, 19-49. Oxford: Oxford University Press.

Haykal, Muhammad Husayn. 1968. Fi awqat al-faragh. al-Qahirah: Maktabat al-nahdah almisriyyah.

Hourani, Albert. 1983. The Arabic Thought in the Liberal Age. Cambridge: Cambridge University Press.

Jameson, Fredric. 1981. The Political Unconscious. Narrative as a Socially Symbolic Act. Ithaca: Cornell University Press.

Le Bon, Gustave. 2001. The Crowds. A study of the popular mind. Kitchener: Batoche Books.

Mahfuz, Najib. 1988. Zuqaq al-midaqq (1947). al-Qahira: Maktabat Misr (Translated by Trevor LeGassick: Mahfuz, Nagib. 1992. Midaq Alley. New York: Anchor Books).

al-Muwaylihi, Muhammad. 1992a. Hadith 'Isa Ibn Hisham aw fatra min al-zaman (1907). Dar aljanub: Tunis. (Translated by Roger Allen: al-Muwaylihi, Muhammad 1992b. A Period of Time. Reading: Garnet Press).

al-San'usi, Sa‘ud. 2015. Fi'ran Ummi Hissa. Bayrut: al-Dar al-‘arabiyya li-l-‘ulum nashirun. (Translated by Sawad Hussain: Alsanousi, Saud. 2019. Mama Hissa’s Mice. Seattle: Amazon Crossing).

Selim, Samah. 2004. The Novel and the Rural Imaginary in Egypt. London: Routledge.

Smith, Charles. 1983. Islam and the Search for Social Order in Modern Egypt. A Biography of Muhammad Husayn Haykal. Albany: State University of New York Press.

Sternhell, Zeev. 2009. The Anti-Enlightenment Tradition. New Haven: Yale University Press.

Tijani, Olatun Bosun. 2017. Kuwait in The Oxford Handbook of Arab Novelistic Traditions, edited by Waïl S. Hassan, 281-295. Oxford: Oxford University Press.

Watt, Ian. 1957. The Rise of the Novel. Berkeley: University of California Press. 
